\title{
Analisis Kepuasan Wisatawan Terhadap Produk Wisata dan Strategi Pengembangan DTW Telaga Wopersnondi Biak Timur
}

Hans S. M. Salakory a, 1, Febby S. Matulessy a, 2, Yansen M. I. Saragih b, 3

${ }^{1}$ hans.salakory@gmail.com, ${ }^{2}$ febbysonya@gmail.com, ${ }^{3}$ Yansen_gbu@yahoo.co.id

aProgram Studi Perencanaan Wilayah dan Kota, Fakultas Teknik Sipil dan Perencanaan Institut Sains dan Teknologi Indonesia (ISTI)

Manokwari, Papua Barat, Jl. Pasir Putih, Bakaro, Papua Barat 98311 Indonesia.

bFakultas Sastra dan Budaya, Universitas Negeri Papua, Jl. Gunung Salju, Manokwari, Papua Barat 98314 Indonesia

\begin{abstract}
Visitors of Wipersnondi Lake had great hope of fulfilling their comfort when they arrived at the tourism sites, in fact the performance felt by visitors cannot satisfy all the expectations of visitors and had impact on their satisfaction and convenience. This study aims to determine the level of satisfaction of tourist visitors to the availability of elements of tourism products, and to find out its developments strategy. To answer the research problem, the analysis technique used is Customer Satisfaction Index (CSI) and Importance Performance Analysis (IPA). The results of research based on CSI show that visitors are not satisfied with the performance of tourism products at Wopersnondi Lake. Based on the results of the IPA analysis, the main priorities for tourism development in Wopersnondi Lake are increasing affordability and opening of public transport routes, improving cleanliness and increasing the number of toilets, specifically at the lake location, providing road directions to the location, and building health facilities like public health centers around Wopersnondi Lake. Furthermore, the unique aspects of Wopersnondi Lake that must be maintained are the beautiful view at the tourist location, the comfort of the tourist attraction, the coolness, the cleanliness, the quality of the road to the lake, the parking lot area, and the availability of trash cans are things that have actually been felt and have created comfort and good experience for visitors to Wopersnondi Lake. This development must support the development of other tourism products..
\end{abstract}

Key Word:Importance Performance Analysis, Customer Satisfaction Index.

\section{PENDAHULUAN}

Suatu daerah yang menjadi tujuan wisata terbentuk secara sistematis oleh tiga elemen, pertama seseorang dengan kebutuhan wisata yang merupakan faktor utama atau pangkal bahwa ada keistimewaan dari suatu daerah sehingga dikunjungi. Faktor-faktor daya tarik wisata sangat berpengaruh terhadap sesorang atau wisatawan dalam melakukan perjalanan wisata, oleh karena itu maka wisatawan akan rela membayar berapapun dan melakukan perjalanan yang jauh hanya untuk menikmatii destinasi wisata yang dia inginkan demikian kata Leipir (Sulistyan et al., 2018). Konsep inilah yang mengharuskan suatu daerah memiliki potensi wisata dan daya tarik wisata (dtw / obyek wisata) kalau daerah tersebut menginginkan daerahnya menjadi daerah tujuan wisata.

Bila wisatawan merasa puas dengan pengalamannya ditempat wisata dan memiliki persepsi yang baik akan objek wisata yang dituju maka wisatawan menentukan pilihan dan perilakunya. Bitner mengatakan bahwa munculnya perilaku wisatawan seperti : atraksi, lama tinggal, membelanjakan uang dan kesediaan mengulang kunjungan adalah merupakan respon positif sebagai aktualisasi dari rasa puas terhadap produk wisata yang ditawarkan di suatu daerah tujuan wisata. Dengan demikian maka persepsi wisatawan merupakan dasar pertimbangan pengembangan objek wisata sesuai dengan kebutuhan pasar (Purnomo, 2010).

Beberapa penelitian tentang kepuasan wisatawan terhadap produk wisata diantaranya adalah: Penelitian yang dilakukan oleh (Madafuri, 2018) menunjukkan bahwa attraction dan amenities berpengaruh signifikan terhadap kepuasan wisatawan. Selanjutnya attraction dan kepuasan wisatawan juga berpengaruh signifikan terhadap loyalitas wisatawan. Wisatawan yang loyal adalah wisatawan yang memiliki pengalaman positif terhadap apa yang dinikmati. Selanjutnya penelitian (Abdulhaji \& Yusuf, 2016) terhadap pengunjung wisata Danau Tolire Besar menemukan bahwa, citra objek wisata bersangkutan secara nyata dipengaruhi oleh atraksi, aksessibilitas dan fasilitas. Selain itu persepsi wisatawan adalah baik terhadap citra objek wisata, atraksi, aksessibilitas dan fasilitas.

Selanjutnya hasil penelitian (Rossadi \& Widayati, 2018) menunjukkan bahwa secara simultan aksesibilitas, amenitas, dan atraksi wisata berpengaruh positif dan signifikan terhadap minat kunjungan wisatawan ke 
wahana air Balong Waterpark, walaupun minat wisatawan untuk berkunjung ke wahana Air Balong Waterpark secara parsial tidak dipengaruhi signifikan oleh atraksi wisata. Selanjunya penelitian (Seprina et al., 2014) menemukan bahwa persepsi wisatawan terhadap Aksesibilitas, Fasilitas. Ketersediaan infrastruktur kurang mendukung, aman dan layak untuk dikunjungi, walaupun fasilitas promosi dan informasi menurut persepsi wisatwan kurang baik. Hasil penelitian (Handayani et al., 2019) yang dilakukan terhadap wisatawan yang berkunjung ke Bangka Botanical Garden (BBG) Pangkalpinang menunjukkan bahwa terdapat pengaruh yang positif dan signifiksan dari variabel fasilitas, aksesibilitas dan daya tarik wisata terhadap variabel kepuasan wisatawan. Kesimpulannya untuk meningkatkan kepuasan pengunjung wisata maka kualitas fasilitas, aksesibilitas dan daya tarik wisata harus semakin ditingkatkan.

Telaga Wopersnondi adalah salah satu destinasi wisata baru di kampung Spese, Samares, Biak Timur yang selama beberapa tahun terakhir sering menjadi perbincangan wisatawan lokal karena keunikan dan kondisi alamnya yang masih asli. Kondisi lokasi telaga memang sangat berbeda jauh bila dibandingkan 2 dan 3 tahun sebelumnya, setelah dikelola oleh masyarakat adat setempat di bantu oleh Dinas Kehutanan, akses jalan menuju Telaga Wopersnondi cukup baik, walaupan sekitar \pm 7 km menuju ke telaga jalannya belum di aspal, tetapi setelah tiba diparkiran jalan menuju telaga telah dibuat jalan setapak semen dan bangku-bangku untuk bersantai dan beristirahat.

Tidak mengabaikan setiap upaya yang telah dilakukan oleh masyarakat kampung Spese dan Pemerintah Daerah, maka perlu diperhatikan apa yang menjadi kebutuhan pengunjung Telaga Wopersnondi, bahwa berwisata merupakan kebutuhan sekunder yang harus dipenuhi oleh setiap Individu setelah kebutuhan primernya terpenuhi, semua orang mengambil keputusan berwisata karena adanya jasa kenyamanan (Amenity) yang ditawarkan dan itulah yang menjadi harapan dan kebutuhan dari mereka.

Hasil wawancara dengan wisatawan didapati informasi bahwa rata-rata pengunjung wisata mengatakan objek wisata ini memiliki pemandangan yang menarik, hutan yang masih asli, selain itu didapati juga informasi bahwa objek wisata Telaga Wopersnondi belum cukup representatif untuk menciptakan kenyamana yang seharusnya dijual kepada para pengunjung wisata Telaga Wopersnondi. Harapan besar akan terpenuhi kenyamanan berwisata berbanding terbalik dengan kenyataan pelayanan yang dirasakan tidak maksimal oleh pengunjung, mulai dari pos keamanan untuk masuk ke kawasan wisata, tidak jelasnya petugas parkir, tidak adanya wahana permainan, kurangnya fasilitas kebersihan, tidak adanya fasilitas kesehatan, serta masih banyak lagi faktor yang tidak berpihak pada kenyaman pengunjung wisata.

Dengan merujuk pada latar belakang dan beberapa penelitian sebelumnya maka masalah dari penelitian ini adalah: "Bagaimana tingkat Kepuasan Wisatawan Terhadap Produk Wisata di Objek Wisata Telaga Wopersnondi, Bagaimana Strategi Pengembangan Objek Wisata Telaga Wopersnondi". Berdasarkan permasalahan maka penelitian ini ditujukan untuk menghitung dan menganalisis kepuasan wisatawan serta membuat strategi pengembangan Objek Wisata Telaga Wopersnondi berdasarkan persepsi pengunjung wisata.

\section{METODE PENELITIAN}

Menurut klasifikasinya maka penelitian ini bersifat deskriptif (Kuncoro, 2003), untuk menentukan sampel digunakan teknik aksidental sampling (Yuniati et al., 2013). Populasi sebanyak 400 orang pengunjung dalam sebulan, maka dipakai metode Slovin untuk menetukan besar sampel (Suharsaputra, 2014):

$$
n=\frac{N}{1+N e^{2}} \quad n=\frac{400}{1+(400)(0,1)^{2}}=80 \text { orang }
$$

Pengumpulan data dilakukan teknik: 1). Observasi (pengamatan). 2). Interview (Wawancara 3). Kuesioner (angket). 4). dokumentasi (Sugiyono, 2013).

Untuk menjawab pertanyaan penelitian digunakan metode Kuantitatif (Suharsaputra, 2014) karena menggunakan data numerik dengan pendekatan statistik. Spesifikasi dari alat analisis meliputi:

1. Uji validitas dan reliabilitas kuisioner. Agar diketahui kelayakan indikator dan konsistensi responden dalam menjawab setiap pertanyaan, Nunnally mengatakan bahwa suatu konstruk dikatakan reliabel jika memberikan nilai Cronbach alpha > 0,6. 
Sementara uji Validitas kuesioner dilakukan dengan membandingkan nilai $\mathrm{R}$ hitung terhadap $\mathrm{R}$ tabel, bila $\mathrm{R}$ hitung lebih besar dari $\mathrm{R}$ tabel maka kuesioner dianggap valid, atau dengan melihat korelasi antar masingmasing indikator terhadap total skor konstruk menunjukan hasil yang signifikan (nilai sig tidak boleh $>0.050$ ) (Ghozali, 2009).

2. Model Customer Satisfaction Index (CSI) digunakan untuk mengetahui tingkat kepuasan pengguna jasa secara menyeluruh dengan melihat tingkat kinerja dan tingkat kepentingan/harapan dari atribut-atribut jasa pelayanan (Sumanga, 2013). Menurut Aritonang (Umam \& Hariastuti, 2018) langkah-langkah dalam analisis CSI adalah; 1). Menentukan Mean Importance Score (MIS) dan Mean Satisfaction Score (MSS). 2). Menghitung Weight Factor (WF) atau faktor tertimbang. Bobot ini merupakan persentase nilai MIS per indikator terhadap total MIS seluruh indikator. 3). Menghitung Weight Score (WS) atau skor tertimbang. Bobot ini merupakan perkalian antara WF dengan ratarata tingkat kepuasan. 4). Menentukan Customer Satisfaction Index (CSI), penjabarannya sebagai berikut:

$$
M I S=\frac{\left(\sum_{i=1}^{n} Y_{i}\right)}{n}
$$

$\mathrm{Yi}=$ nilai kepentingan atribut $\mathrm{Y}$ ke $\mathrm{i}$

$\mathrm{n} \quad=$ Jumlah Responden

$M S S=\frac{\left(\sum_{i=1}^{n} Y_{i}\right)}{n}$

$\mathrm{Yi}=$ nilai kepuasan atribut $\mathrm{Y}$ ke $\mathrm{i}$

$\mathrm{n}=$ Jumlah Responden

$W F=\frac{M I S i}{\left(\sum_{i=1}^{p} M S I i\right)} \times 100 \%$

MISi = Nilai rata-rata kepentingan ke i

$\sum_{i=1}^{p} M S I i=$ Total rata-rata kepentingan dari

ke-i ke-p

$W S i=W F i \times M S S$

$\mathrm{WFi}=\quad$ Faktor tertimbang ke $\mathrm{i}$

$$
\begin{aligned}
& C S I=\frac{\left(\sum_{i=1}^{p} W S i\right)}{H S} \times 100 \% \\
& \mathrm{HS}=\quad \text { High Score }
\end{aligned}
$$

Bila nilai CSI > 50\% maka dapat dikatakan bahwa pengguna jasa telah merasa puas, sebaliknya bila CSI $<50 \%$ maka pengguna jasa belum merasa puas. Nilai CSI dalam penelitian ini dibagi dalam lima kriteria dari tidak puas sampai dengan sangat puas (Sumanga, 2013).

3. Model Importand Performance Analissys (IPA) (Supranto, 2011) terdapat dua buah variabel yang diwakilkan oleh huruf $\mathrm{X}$ dan huruf $\mathrm{Y}$, dimana $X$ merupakan tingkat kinerja produk wisata, dan $\mathrm{Y}$ merupakan tingkat harapan pengunjung wisata terhadap ketersediaan produk wisata, tingkat kesesuaian inilah yang akan menentukan prioritas peningkatan strategi. Adapun rumus yang digunakan adalah :

$T k i=\frac{X i}{Y i} x 100 \%$

$\mathrm{Tki}=$ tingkat kesesuaian responden

$\mathrm{Xi}=$ skor penilaian Jasa Yang diperoleh (Atraksi Wisata, Eksesibelitas, Kondisi Fasilitas Tampat Wisata) di Telaga Wopersnondi

Yi = skor penilaian kepentingan pelanggan . Dengan kriteria pengukuran (Kasmari \& Marlien, 2018) :1) 0-32 \% Sangat Tidak Puas, 2) 33-65\% Tidak Puas, 3) 66 - 99\% Kurang Puas, 4) 100\% Memuaskan, 5) > 100\% Sangat Memuaskan.

Selanjutnya sumbu mendatar (X) akan diisi oleh skor tingkat pelaksanaan kinerja, sedangkan sumbu tegak (Y) akan diisi oleh skor tingkat harapan. Dalam penyederhanaan rumus, maka untuk setiap faktor yang mempengaruhi kepuasan pelanggan dengan :

$\bar{X}=\frac{\sum X i}{n} \quad \bar{Y}=\frac{\sum Y i}{n}$

Dimana :

$\widetilde{X}$ = skor rata-rata tingkat pelaksanaan/kinerja

$\tilde{Y}$ = skor rata-rata tingkat kepentingan/harapan

$\mathrm{N}=$ jumlah responden

Diagram Kartesius merupakan suatu bangun yang dibagi atas empat bagian yang dibatasi oleh dua buah garis yang berpotongan tegak lurus pada $(\overline{\bar{X}}, \overline{\bar{Y}}) \quad$ titik-titik dimana $\overline{\bar{X}}$ merupakan rata-rata skor tingkat pelaksanaan atau kepuasan konsumen seluruh faktor atau atribut dan $\overline{\bar{Y}}$ adalah rata-rata skor tingkat kepentingan seluruh faktor yang mempegaruhi kepuasan pelanggan.

Rumus selanjutnya :

$$
\begin{aligned}
& \overline{\bar{X}}=\frac{\sum_{i=1}^{n} \bar{X} i}{K} \\
& \overline{\bar{Y}}=\frac{\sum_{i=1}^{n} \bar{Y} i}{K}
\end{aligned}
$$

Dimana $\mathrm{K}$ = banyaknya atribut/fakta yang dapat mempengaruhi kepuasan pelanggan. Selanjutnya tingkat unsur-unsur tersebut akan dijabarkan dan dibagi menjadi empat bagian ke dalam diagram Kartesius. Dari sini, diketahui mana indikator-indikator yang merupakan prestasi dan perlu dipertahankan. Selain itu juga 
diketahui mana indikator-indikator yang kualitasnya tidak bagus.

Untuk dapat melihat posisi penempatan data yang telah dianalisis tersebut, maka dapat dibagi empat bagian:

1. Kuadran A, menunjukkan faktor atau atribut yang dianggap mempengaruhi kepuasan pelanggan, termasuk unsur-unsur jasa yang dianggap sangat penting, namun manajemen belum melaksanakannya sesuai keinginan pelanggan. Sehingga mengecewakan/tidak puas.

2. Kuadran B, menunjukkan unsur jasa pokok yang telah berhasil dilaksanakan manajemen, untuk itu wajib dipertahankan. Dianggap sangat penting dan sangat memuaskan.

3. Kuadran $\mathrm{C}$ menunjukkan beberapa faktor yang kurang penting pengaruhnya bagi pelanggan, pelaksanaannya biasa-biasa saja. Dianggap kurang penting dan kurang memuaskan bagi pelanggan.

4. Kuadran D menunjukkan faktor yang mempengaruhi pelanggan kurang penting, akan pelaksanaannya berlebihan. Dianggap kurang penting tetapi sangat memuaskkan.

\section{III.HASIL DAN PEMBAHASAN}

Telaga Wopersnondi adalah sebuah destinasi wisata baru di Papua, di kampung Spese Distrik Biak Timur, tempat ini berjarak $\pm 52,3 \mathrm{~km}$ dari kota Biak, ditempuh lewat jalan darat dengan waktu tempuh \pm 2 jam. Keistimewaannya adalah warna air-nya biru yang menjadi pembeda telaga ini dengan telaga pada umumnya. Telaga Wopersnondi memilki air yang jernih sehingga pengunjung dapat melihat pemandangan hingga ke dasar telaga yang mencapai $\pm 50 \mathrm{~m}$. Berdasarkan hasil wawancara dengan kepala kampung Spese yang sekaligus sebagai ketua tim pengelola Objek wisata Telaga Wopersnondi bahwa nama Wopersnondi terdiri dari 2 kata yaitu Woper yang artinya Hantu dan Snondi yang artinya lakilaki. Sesuai namanya, telaga ini menyimpan banyak rahasia, karenanya warga kampung Spese sangat mengsakralkan tempat ini, oleh karena itu setiap pengunjung dianjurkan menghargai tempat tersebut dengan tidak melakukan perbuatan yang tidak pantas dan tidak senono di sekitar telaga tersebut.

\section{Uji Kelayakan Kuisioner}

Dari uji reliabilitas didapati angka Cronbach's Alpha untuk Kinerja 0,769 dan Harapan 0,969, keduanya lebih besar dari 0,60 berarti reliebel, responden menjawab dengan konsisten. Untuk uji validitas kuisioner didapati nilai sig untuk seluruh indikator adalah 0,00 artinya semua butir pertanyaan valid dan layak untuk dilanjutkan dalam proses analisis.

\section{Analisis Kepuasan Pengunjung Wisata Telaga Wopersnondi}

Produk wisata memiliki peran yang besar terhadap kemajuan sektor pariwisata, produk wisata yang representatif akan memberikan dampak bagi kepuasan pengunjung wisata di objek wisata bersangkutan, dengan tingkat kepuasan maksimal, pengunjung wisata akan memutuskan untuk melakukan perjalan wisata kembali ke objek wisata bersangkutan, bahkan dia akan menganjurkan kepada orang lain, tetapi bila keberadaan produk wisata tidak mampu menciptakan kepuasan maksimum maka kondisi sebaliknya akan terjadi.

Produk wisata adalah berbagai jenis jasa dimana satu dengan lainnya saling terkait yang dihasilkan oleh berbagai usaha pariwisata, misalnya: usaha perjalanan wisata, penyediaan akomodasi, transportasi wisata, jasa makanan dan minuman, daya tarik wisata, penyelenggaraan kegiataan hiburan dan rekreasi serta perusahaan lain yang terkait (Muljadi \& Warman, 2014). Baud-Bovy mengemukakan bahwa Produk pariwisata adalah sejumlah fasilitas dan pelayanan yang disediakan dan diperuntukkan bagi wisatawan, yang terdiri dari tiga komponen, masing-masing yaitu sumber daya yang terdapat pada suatu DTW, fasilitas yang terdapat di suatu DTW, dan transportasi yang membawa wisatawan dari tempat asalnya ke suatu DTW tertentu (Yoeti, 2005). Produk dalam industri pariwisata merupakan kombinasi dari tiga komponen yang dianggap sangat penting, yang satu denga lainnya saling melengkapi, yaitu: 1). The Accesibilities of the destination adalah semua faktor yang memberikan kemudahan kepada wisatawan untuk berkunjung pada suatu DTW. 2). The Fascilities of the destination Fadalah semua faktor yang dapat meberikan pelayanan terhadap kebutuhan bagi wisatwan di DTW. 3). The Tourist Attractions of the detination yakni semua yang menjdi daya tarik sihingga wisatawan mau datang ke suatu DTW (Yoeti, 
2005). Oliver mengatakan bahwa kepuasan adalah tingkat perasaan seseorang setelah membandingkan kierja/hasil yang dirasakan dengan harapannya (Supranto, 2011). Umar mengatakan bahwa sangat besar kemungkinannya seorang pelanggan untuk menjadi pelanggan dalam waktu yang lama atau dengan kata lain menjadi pelanggan setia jika dia merasa puas dengan nilai yang didapatkan dan rasakan dari suatu produk barang atau jasa (Syahri et al., 2018). konsumen melakukan perbandingan antara kinerja suatu produk dengan apa yang menjadi ekspektasinya maka akan muncul rasa puas atau tidak dan inilah yang disebut dengan tingkat kepuasan konsumen. Jika kinerja gagal memenuhi ekspektasi maka pelanggan akan tidak puas, dan sebaliknya (Kotler \& Keller, 2013).

Ungkapan rasa puas dan tidak disebut sebagai persepsi. Berkaitan dengan pengembangan objek wisata Telaga Wopersnondi maka pentinglah untuk diketahui persepsi wisatawan terhadap apa yang dia rasakan selama berkunjung dan merasakan suguhan produk wisata yang disediakan. Persepsi wisatawan menentukan preferensi dan perilakunya. Persepsi wisatawan memberikan gambaran akan terpenuhinya harapan ketika terjadi penyerahan jasa di tempat wisata, dengan demikian maka persepsi wisatawan merupakan dasar pertimbangan pengembangan objek wisata.

Berdasarkan hasil perhitungan di dapati nilai Weight Total (WT) atau Weight Score (WS) total adalah sebesar 222,86, High Score (HS) pada skala likert yang dibuat adalah 5, maka dapat ditentukan nilai CSI sebagai Berikut:

Tabel 1

Perhitungan CSI Atas Persepsi Pengunjung Wisata

\begin{tabular}{|c|c|c|c|c|c|}
\hline Harapan & MIS & Kinerja & MSS & $\mathrm{WF}$ & WS \\
\hline h1 & 4,93 & K1 & 4,88 & 3,58 & 17,46 \\
\hline h2 & 4,84 & K2 & 4,69 & 3,52 & 16,49 \\
\hline h3 & 4,86 & K3 & 4,19 & 3,54 & 14,81 \\
\hline h4 & 4,86 & K4 & 4,88 & 3,54 & 17,24 \\
\hline h5 & 4,85 & K5 & 4,25 & 3,53 & 14,99 \\
\hline h6 & 4,88 & K6 & 3,69 & 3,55 & 13,07 \\
\hline h7 & 4,81 & K7 & 1,81 & 3,50 & 6,34 \\
\hline h8 & 4,56 & K8 & 1,13 & 3,32 & 3,73 \\
\hline h9 & 4,60 & K9 & 3,00 & 3,35 & 10,04 \\
\hline h10 & 3,59 & K10 & 1,88 & 2,61 & 4,89 \\
\hline h11 & 4,41 & K11 & 1,91 & 3,21 & 6,14 \\
\hline h12 & 4,74 & K12 & 3,50 & 3,45 & 12,06 \\
\hline h13 & 4,16 & K13 & 4,13 & 3,03 & 12,49 \\
\hline h14 & 3,66 & K14 & 2,63 & 2,66 & 6,99 \\
\hline h15 & 4,80 & K15 & 1,63 & 3,49 & 5,67 \\
\hline h16 & 4,21 & K16 & 1,38 & 3,06 & 4,21 \\
\hline h17 & 4,35 & K17 & 1,38 & 3,16 & 4,35 \\
\hline h18 & 4,40 & K18 & 4,38 & 3,20 & 14,00 \\
\hline h19 & 4,34 & K19 & 1,63 & 3,15 & 5,13 \\
\hline h20 & 4,54 & K20 & 1,38 & 3,30 & 4,54 \\
\hline h21 & 4,61 & K21 & 1,38 & 3,35 & 4,61 \\
\hline h22 & 4,51 & K22 & 4,75 & 3,28 & 15,59 \\
\hline h23 & 4,43 & K23 & 1,38 & 3,22 & 4,43 \\
\hline h24 & 3,59 & K24 & 1,38 & 2,61 & 3,59 \\
\hline & & & \multicolumn{2}{|c|}{ Total WSi } & 222,86 \\
\hline
\end{tabular}

Sumber: Hasil Penelitian diolah kembali, 2018

Berdsarkan perhitungan pada tabel $1 \mathrm{di}$ atas maka nilai CSI dapat dihirung sebagai berikut:

$C S I=\frac{\left(\sum_{i=1}^{p} W S i\right)}{H S} \times 100 \%$
$C S I=\frac{(222,86)}{5} \times 100 \%=44,57 \%$

Angka $44,57 \%$ berarti pengunjung belum merasa puas, penyebab adalah karena hampir sebagian besar ketersediaan produk wisata 
belum mampu menciptakan kepuasan bagi wisatawan, hal ini sejalan dengan pendapat Sumarwan (Guspul \& Ahmad, 2014) yang mengatakan, pelanggan akan menjadi kecewa ketika kinerja dibawah harapandan ekspektasinya, sebaliknya konsumen akan merasa puas apabila hasil kinerja sesauai dengan harapan/ekspektesai mereka. bila hasil sesuai dengan harapan maka konsumen akan puas. Konsumen atau pelanggan yang puas akan memiliki loyalitas terhadap produk dan mereka kurang sensitif terhadap harga. Konsumen yang bersangkutan akan memiliki persepsi yang baik terhadap produk yang dia rasakan (Maulana, 2016).

\section{Strategi Pengembangan}

Untuk menentukan strategi pengembangan produk wisata di objek wisata maka perlu diketahui tingkat harapan wisatawan dan kinerja yang ditunjukan pengelola menurut persepsi responden. Berikut pada tabel 2 menunjukan persepsi dan tingkat kepuasan pengunjung wisata tentang Kondisi Atraksi Wisata Telaga Wopersnondi:

Tabel 2

Persepsi Tentang Kondisi Atraksi Wisata Telaga Wopersnondi

\begin{tabular}{rlrrr}
\hline No & Kondisi Atraksi Wisata & Kinerja & Harapan & \multicolumn{2}{c}{ Kesesuaian } \\
\hline A & Keunikan Telaga Wopersnondi & 4,88 & 4,93 & 98,98 \\
\hline B & Keindahan Pemandangan di Telaga Wopersnondi & 4,69 & 4,84 & 96,90 \\
\hline C & Kenyamanan Objek Wisata Telaga Wopersnondi & 4,19 & 4,86 & 86,12 \\
\hline D & Kesejukan Telaga Wopersnondi & 4,88 & 4,86 & 100,26 \\
\hline E & Kebersihan Telaga Wopersnondi & 4,25 & 4,85 & 87,63 \\
\hline & Rerata & 4,58 & 4,87 & 93,98 \\
\hline
\end{tabular}

Sumber: Hasil Penelitian diolah kembali, 2018

Berdasarkan hasil perhitungan pada tabel 2, persepsi wisatawan baik dari sisi performance (kenyataan yang didapati) serta importance (harapan/kepentingan) diperoleh skor 4,58 dan 4,87 yang lebih dekat pada skor, dan tingkat kesesuaiannya mencapai 0,9398

atau $93,98 \%$ berada pada skala 66\%-99\%, artinya pengunjung wisata kurang puas dengan atraksi wisata di Telaga Wopersnondi. Tabel 3 berikut menunjukan persepsi pengunjung wisata terhadap Eksebilatas.

\section{Tabel 3}

Persepsi Wisatawan tentang Eksebilitas Menuju Telaga Wopersnondi

\begin{tabular}{clrrr}
\hline No & Kondisi Eksebilitas & Kinerja & Harapan & Kesesuaian \\
\hline F & Kualitas Jalan Menuju Telaga Wopersnondi & 3,69 & 4,88 & 75,64 \\
\hline G & Keterjangkauan Angkutan Umum Ke Telaga Wopersnondi & 1,81 & 4,81 & 37,66 \\
\hline H & Bagaimana Kualitas Angkutran Umum & 1,13 & 4,56 & 24,66 \\
\hline I & Kulitas jalan utama yang terdekat dengan Telaga Wopersnondi & 3,00 & 4,60 & 65,22 \\
\hline J & Bagaimana Kondisi Rambu Lalulitas Menuju Telaga Wopersnondi & 1,88 & 3,59 & 52,26 \\
\hline K & Bagaimana Kondisi Penunjuk Arah Menuju Telaga Wopersnondi & 1,91 & 4,41 & 43,34 \\
\hline & Rerata & 2,24 & 4,48 & 49,80 \\
\hline
\end{tabular}

Sumber: Hasil Penelitian diolah kembali, 2018

Dari tabel 3 didapati persepsi wisatawan terhadap eksesibilitas menuju Telaga Wopersnondi angka kinerja bernilai 2,24 yang kalau dibulatkan nilainya 2 artinya Tidak Baik, aspek harapan/kepentingan diperoleh skor 4,84 dibulatkan menjadi 5 artinya sangat penting sekali, dengan tingkat kesesuaian sebesar 49,80\%, angka ini berada pada skala 33\%-65\% yang berarti pengunjung wisata tidak puas dengan kondisi eksebilitas menuju objek wisata Telaga Wopersnondi.

Tabel 4 berikut menunjukkan kinerja dan harapan pengunjung wisata terhadap kondisi fasilitas tempat wisata Telaga Wopersnondi

\section{Tabel 4}

Persepsi Wisatawan Tentang Kondisi Fasilitas Tempat Wisata

\begin{tabular}{clrrr}
\hline No & Kondisi Fasilitas Tempat Wisata & Kinerja & Harapan & \multicolumn{1}{c}{ Kesesuaian } \\
\hline L & Luas Tempat Parkir & 3,50 & 4,74 & 73,88 \\
\hline
\end{tabular}




\begin{tabular}{llrrr}
\hline M & Kemanan Tempat Parkir & 4,13 & 4,16 & 99,10 \\
N & Ketrampilan Juru Parkir & 2,63 & 3,66 & 71,67 \\
\hline O & Keberhasilan Toilet & 1,63 & 4,80 & 33,85 \\
\hline P & Jumlah Toilet & 1,38 & 4,21 & 32,64 \\
\hline Q & Akses Pusat Informasi & 1,38 & 4,35 & 31,61 \\
\hline R & Tempat Istirahat & 4,38 & 4,40 & 99,43 \\
\hline S & Rumah Makan & 1,63 & 4,34 & 37,46 \\
\hline T & Petunjuk Jalan Menuju Lokasi & 1,38 & 4,54 & 30,30 \\
\hline U & Sarana Kesehatan & 1,38 & 4,61 & 29,81 \\
\hline V & Ketersediaan Tempat Sampah & 4,75 & 4,51 & 105,26 \\
\hline W & Toko Cindra Mata & 1,38 & 4,43 & 31,07 \\
\hline X & Fasilitas Penginapan & 1,38 & 3,59 & 38,33 \\
\hline & Rerata & 2,38 & 4,33 & 54,96 \\
\hline
\end{tabular}

Sumber: Hasil Penelitian diolah kembali, 2018

Dari tabel 4 di atas terlihat bahwa persepsi wisatawan terhadap kondisi fasilitas wisata di Telaga Wopersnondi dari aspek performance (Kenyataan yang didapai) hanya bernilai 2,38 yang kalau dibulatkan nilainya 2 artinya Tidak Baik, sementara dari aspek importance (Harapan/kepentingan) diperoleh skor 4,30 dibulatkan menjadi 4 bernilai Sangat Baik, terjadi gap sekitar $(1,93)$ dan tingkat kesesuaian antara kinerja terhadap harapan adalah sebesar $54,96 \%$ angka ini berada rentan 33\%-65\% yang berarti pengunjung wisata Telaga Wopersnondi hanya berada pada kondisi tidak puas.

Merangkum semua kinerja dan harapan pengunjung wisata terhadap atribut produk wisata Telaga Wopersnondi maka kita mendapat angka kesesuaian sebesar $68,55 \%$ angak ini berada pada rentan 66\%-99\% artinya secara komulatif pengunjung wisata Telaga Wopersnondi kurang puas terhadap produk wisata yang disiapkan oleh pengelola.

\section{Penentuan Strategi Pengembangan}

Penentuan strategi pengembangan objek wisata Telaga Wopersnondi maka analisis performance dan importance dan GAP yang telah dilakukan sebelumnya dilanjutkan dngan analisis diagram Kartesius untuk kemudian dari hasil analisis melahirkan strategi pengembangan yang paling tidak bisa memenuhi harapan wisatawan.

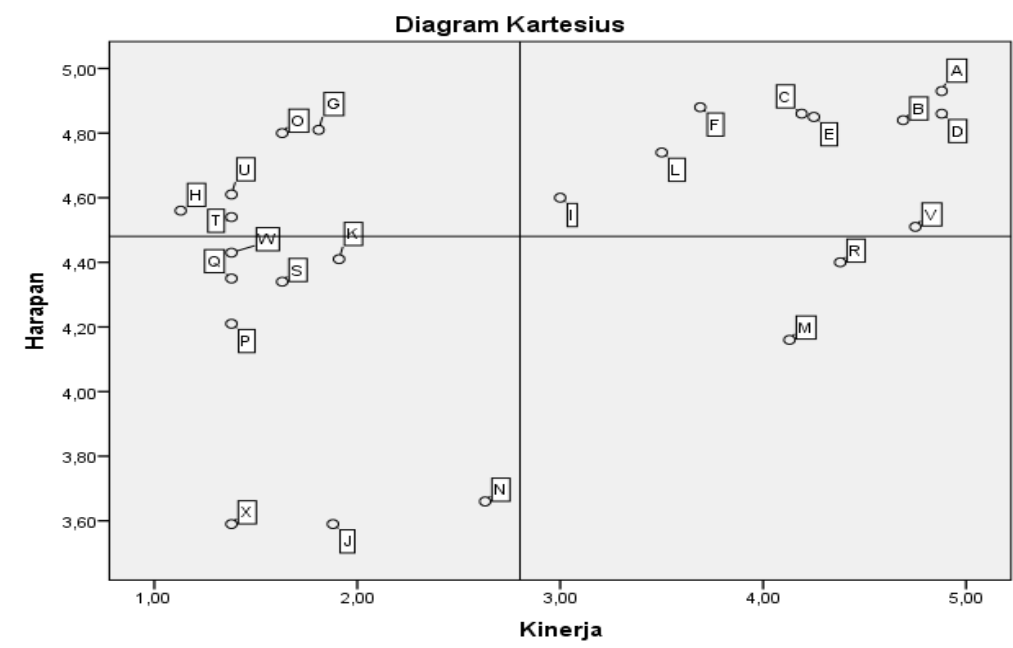

Gambar 1

\section{Diagram Kartesius Persepsi Pengunjung Wisata akan Harapan dan Kinerja}

Berdasarkan persebaran indikator atau titik GAP antara kinerja dan harapan konsumen pada empat kuadran seperti yang terlihat pada gambar 1 diatas melahirkan 4 strategi sebagai berikut:
1. Kuadran A, menunjukkan faktor atau atribut yang dianggap mempengaruhi kepuasan pelanggan, termasuk unsur-unsur jasa yang dianggap sangat penting, namun manajemen belum melaksanakannya sesuai keinginan 
pelanggan sehingga mengecewakan/tidak puas. Kuandran ini dianggap menjadi prioritas utama karena indikator-indikator produk wisata pada kuadran ini dianggap penting bagi pengunjung wisata tetapi secara kinerja belum mampu memberikan kepuasan bagi pengujung wisata. Indikator yang termasuk dalam kuadran ini adalah $\mathrm{G}$ (Keterjangkauan Angkutan Umum), $\mathrm{H}$ (Kualitas Angkutan Umum), T (Petunjuk Jalan Menuju Lokasi), U (Sarana Kesehatan), 0 (Keberhasilan Toilet).

2. Kuadran B, menunjukkan unsur jasa pokok yang telah berhasil dilaksanakan manajemen atau pengelola tenpat wisata, untuk itu wajib dipertahankan. Kuandran ini dianggap sangat penting dan sangat memuaskan, bagi pengelola kawasan wisata. Kuandaran ini menunjukan perlu adanya strategi untuk mempertahankan prestasi, karena wisatawan mengganggap bahwa kinerja yang ditunjukan telah memberikan kepuasan baginya atau sesuai dengan harapan dan ekspektasinya. Indikator komponen produk wisata yang berada pada diagram ini meliputi A (Keunikan), B (Keindahan), C (Kenyamanan), D (Kesejukan), E (Kebersihan), F (Kualitas Jalan Menuju), I (Kualitas Jalan Utama), L (Luas Tempat Parkir), V (Ketersediaan Tempat Sampah).

3. Kuadran $\mathrm{C}$ menunjukkan beberapa faktor yang kurang penting pengaruhnya bagi pelanggan, pelaksanaannya biasa-biasa saja. Dianggap kurang penting dan kurang memuaskan bagi pelanggan. Kuadran ini dianggap "prioritas rendah" karena persepsi pengunjung wisata baik dari sisi harapan maupun tingkat kinerja adalah rendah. Walaupun prioritas rendah tetapi jangan diabaikan dalam pengembangan wisata karena merupakan pendukung bagi unsur produk wisata lainnya. Indikator yang terdapat pada kuadran ini adalah indikator J (Kondisi Rambu Lalu Lintas), K (Konidisi Penunjuk Arah), N (Ketrampilan Juru Parkir), P (Jumlah Toilet), Q (Akses Pusat Informasi), S (Rumah Makan), W (Toko Cindera Mata), X (Penginapan).

4. Kuadran D menunjukkan faktor yang mempengaruhi pelanggan kurang penting, akan pelaksanaannya berlebihan. Dianggap kurang penting tetapi sangat memuaskkan.
Indikator-indikator yang terdapat dalam kuadran ini di katakan berlebihan karena kinerjanya berlebihan dibandingkan ekspektasi atau harapan pengunjung wisata. Dari indikator yang berada pada kuadran ini dapat ditarik kesimpulan bahwa pengelola lebih fokus pada atribut yang sebenarnya secara harapan dan ekspktasi adalah rendah bagi pengunjung wisata. Seharusnya alokasi sumber daya lebih banyak diarahkan pada indiktor yang sebenarnya dianggap penting bagi pengunjung wisata namun dari sisi kinerja tidak maksimal memenuhi harapan wisatawan. Indikator produk wisata yang berada pada kuadran ini adalah indikator $\mathrm{R}$ (Tempat Istirahat) dan indikator $\mathrm{M}$ (Keamanan Tempat Parkir).

Karena indikator keterjangkauan angkutan umum, kebersihan toilet, petunjuk jalan menuju lokasi, dan sarana kesehatan adalah indikator yang memiliki tingkat harapan yang tinggi tetapi tingkat kinerjanya rendah maka baik pengelola maupun pemerintah harus meningkatkan pelayanannya berupa pembukaan jalur angkutan umum menuju tempat-tempat wisata di Kabupaten Biak terutama ke Telaga Wopersnondi agar wisatawan semakin mudah berkunjung ke sana, selanjutnya kondisi toilet yang tidak terpelihara dengan baik dan hanya berjumlah 2 buah itupun jaraknya jauh dari titik spot menyebabkan pengunjung kecewa dengan kondisi tersebut, dengan tidak adanya petunjuk jalan menuju Telaga Wopersnondi menyebabkan pengunjung mengira-ngira jalan bahkan ada pengunjung yang sempat tersesat, hal ini tentunya akan memperlambat tiba ke tujuan. Sarana kesehatan berupa puskesmas bantuan perlu dibangun untuk melayani pengunjung wisata.

Selanjutnya indikator Keunikan Telaga Wopersnondi, keindahan pemandangan, kenyamanan objek wisata, kesejukan, kebersihan, kulitas jalan menuju telaga, luas tempat parkir, ketersediaan tempat sampah adalah hal yang mesti dipertahankan oleh pengelola dan pemerintah daerah karena indikator-indikator ini memiliki tingkat kepentingan dan harapan yang tinggi serta kinerjanya juga tinggi sehingga mampu menciptakan pengalaman dan rasa nyaman dari wisatawan. Perlu diperhatikan juga bahwa pengembangan produk wisata dengan prioritas 
tinggi, dan produk yang harus dipertahankan kinerjanya jangan sampai diabaikan produk wisata yang berada pada prioritas rendah dan berlebihan karena semuanya merupakan satu kesatuan utuh yang dapat memberikan kontribusi yang sama terhadap kepuasan wisatawan dan perkembangan objek wisata Telaga Wopersnondi serta pariwisata Biak pada umumnya.

\section{PENUTUP}

Tingkat kepuasan dan kenyamanan pengunjung berdasarkan perhitungan CSI adalah sebesar 44,57\%, berada pada skala $35 \%-50,9 \%$ kriteria kurang puas, artinya komponen produk wisata yang disiapkan oleh pengelola belum mampu menciptakan kepuasan total terhadap pengunjung wisata.

Prioritas utama pengembangan wisata Telaga Wopersnondi adalah peningkatan keterjangkauan dan pembukaan jalur angkutan umum menuju objek wisata, peningkatan kebersihan dan penambahan jumlah toilet terutama di lokasi telaga, pengadaan petunjuk jalan menuju lokasi, dan pembangunan sarana kesehatan berupa puskemas bantuan di sekitar Telaga Wopersnondi. Aspek keunikan Telaga Wopersnondi harus tetap dijaga, keindahan pemandangan dilokasi wisata, kenyamanan objek wisata, kesejukan, kebersihan, kulitas jalan menuju Telaga, luas tempat parkir, dan ketersediaan tempat sampah adalah hal-hal yang secara idiil sudah dirasakan dan telah menciptakan kenyamanan dan pengalaman baik bagai pengunjung wisata Telaga Wopersnondi.

Pengelola dan pemerintah daerah harus membuka jalur angkutan umum ataupun menuju objek wisata, fasilitasfasilitis pendukung seperti toilet, penunjuk arah, serta fasilitas kesehatan perlu di sediakan selain karena merupakan kebutuhan dasar dari pengunjung wisata tetapi juga menunjukan keseriusan pengelola dan pemerintah dalam upaya mengembangkan objek wisata Telaga Wopersnondi dan kepariwisataan Biak pada umumnya.

Penelitian memiliki keterbatasan terutama waktu penelitian dengan jarak tempuh yang cukup jauh maka bagi peneliti sesudahnya diharapkan melakukan penelitian yang lebih komperhansif guna menjawab sekaligus memberikan solusi guna pengembangan objek wisata Telaga Wopersnondi semakin lebih baik.

Mengingat sektor pariwisata merupakan sektor penyumbang terbesar bagi perekonomian maka Pemerintah daerah sebagai pemegang tugas melakukan pembangunan sarana publik diharapkan mengarahkan dan mencurahkan perhatiannya untuk membangun sarana prasaran pendukung wisata di daerah terutama menuju dan di tempat wisata Telaga Wopersnondi.

\section{DAFTAR PUSTAKA/REFERENSI}

Abdulhaji, S., \& Yusuf, H. S. I. (2016). Pengaruh Atraksi, Aksesibilitas, Dan Fasilitas Terhadap Citra Objek Wisata Danau Tolire Besar Di Kota Ternate. Penelitian Humano, 7(2), $\quad$ 134-148. https://doi.org/http://dx.doi.org/10.33387/hjp.v7i2.317

Ghozali, I. (2009). Aplikasi Analisis Multivariate Dengan Program SPSS (Cetakan IV). Badan Penerbit Universitas Diponegoro.

Guspul, A., \& Ahmad, A. (2014). Kualitas Pelayanan, Kepuasan Dan Kepercayaan Nasabah Pada Koperasi Jasa Keuangan Syariah Di Wonosobo. Penelitian Dan Pengabdian Kepada Masyarakat (PPKM) UNSIQ, 1(3), 156-170. https://doi.org/https://doi.org/10.32699/ppkm.v1i3.253

Handayani, S., Khairiyansyah, \& Wahyudin, N. (2019). Fasilitas. Aksesibilitas dan Daya tarik Wisata Terhadap Kepuasan Wisatawan. Manajemen Dan Bisnis, 20(2), 123-133. https://doi.org/https://doi.org/10.30596/jimb.v20i2.322 8

Kasmari, \& Marlien, R. A. (2018). Tingkat Kepuasan Mahasiswa Terhadap Kualitas Pelayanan Pada Universitas Stikubank Semarang. Jurnal Dinamika Teknik, 11(1), 22-38. https://www.unisbank.ac.id/ojs/index.php/ft1/article/vie $\mathrm{w} / 5623 / 1723$

Kotler, P., \& Keller, L. K. (2013). Manajen Pemasaran (13th ed.). Penerbit Erlangga.

Kuncoro, M. (2003). Metode Riset Untuk Bisnis \& Ekonomi, Bagaimana Meneliti \& Menulis Tesis? Penerbit Erlangga.

Madafuri, B. (2018). Pengaruh Attraction, Amenities, Dan Accessibilities Terhadap Kepuasan Dan Loyalitas Wisatawan Pada Pantai Pulau Merah Di Kabupaten Banyuwangi [Jember] https://repository.unej.ac.id/bitstream/handle/12345678 9/93090/Bintang Madafuri150820101019.pdf?sequence=1\&isAllowed=y

Maulana, S. A. (2016). Pengaruh Kualitas Pelayanan Dan Harga Terhadap Kepuasan Pelanggan PT.TOI. Jurnal Ekonomi Universitas Esa Unggul, 7(2), 113-125. https://www.neliti.com/publications/78663/pengaruhkualitas-pelayanan-dan-harga-terhadap-kepuasanpelanggan-pt-toi

Muljadi, A. J., \& Warman, A. H. (2014). Kepariwisataan dan Perjalanan. PT. Raja Grafindo Persada.

Purnomo, C. (2010). Persepsi Wisatawan Mancanegara Terhadap Mutu Produk Wisata Di Kabupaten Bantul. EfEktif Jurnal Bisnis Dan Ekonomi, 1(1), 43-53. http://jurnalefektif.janabadra.ac.id/wpcontent/uploads/2016/04/4.-Cahyo-Purnomo.pdf

Rossadi, L. N., \& Widayati, E. (2018). Pengaruh Aksesabilitas, Amenitas, dan Atrakasi Wisata Terhadap Minat Kunjungan Wisatawan ke Wahana Air Balong Waterpark Bantul Daerah Istimewa Yogyakarta. Journal of Tourism and Economic, 1(2), 109-116. https://doi.org/https://doi.org/10.36594/jtec.v1i2.27 
Vol. 8 No 2, 2020

Seprina, H., Rosana, \& Nugraheni Lusi Irma. (2014). Persepsi Wisatawan Terhadap Obyek Wisata Air Terjun Way Lalaan Di Kabupaten Tanggamus Tahun 2013. Jurnal Penelitian Geografi, 2(5), 1-8. http://jurnal.fkip.unila.ac.id/index.php/jpg/article/view/ $5791 / 3568$

Sugiyono. (2013). Memahami Penelitian Kualitatif. Penerbit CV. Alfabeta.

Suharsaputra, U. (2014). Metode Penelitian Kuantitatif, Kualitatif, dan Tindakan (F. N. Atif (ed.); kedua). PT. Refika Aditama.

Sulistyan, B. R., Irdiana, S., \& Pradesa, A. H. (2018). Pengembangan destinasi dan daya tarik wisata air terjun sebagai daerah tujuan wisata. Seminar Nasional Sistem Informasi (Senasif) 2018, 2(1), 1438-1447. https://jurnalfti.unmer.ac.id/index.php/senasif/article/vi ew/165

Sumanga, U. A. (2013). Analisis Kepuasan Pengguna Jasa Terhadap Penerapan. Media Engineering, 3(1), 6-13. https://media.neliti.com/media/publications/99768-IDanalisis-kepuasan-pengguna-jasa-terhadap.pdf

Supranto, J. (2011). Pengukuran Tingkat Kepuasan Pelanggan, Untuk Menaikkan Pangsa Pasar. Penerbit Rineka Cipta.

Syahri, D., Pratama, I. M., \& Gustiara Yesy. (2018). Pengaruh Kualitas Produk Dan Kualitas Layanan Terhadap Kepuasan Konsumen Restoran Karibia Seafood Medan. Tansiq, 1(2), 105-119.

http://jurnal.uinsu.ac.id/index.php/tansiq/article/downlo ad/2952/1734

Umam, K. R., \& Hariastuti, P. N. (2018). Analisis kepuasan pelanggan dengan menggunakan metode Customer Satisfaction Index (CSI) dan Importance Performance Analysis (IPA). Seminar Nasional Sains Dan Teknologi Terapan, 339-344. https://ejurnal.itats.ac.id/sntekpan/article/download/36 $6 / 231$

Yoeti, O. A. (2005). Perencanaan Strategis pemasaran daerah tujuan wisata. Pradnya Paramita.

Yuniati, I., Setiawan, A., \& Indrianingsih, Y. (2013). Sistem Pendukung Keputusan Pemilihan Kota Tujuan Wisata Wilayah Jawa Bali Menggunakan Metode Aksidental Sampling (Studi Kasus Di Gras Tour and Travel $\begin{array}{llll}\text { Yogyakarta). } & \text { Compiler, } & 2(2), & 89-96 .\end{array}$ https://doi.org/doi.org/10.28989/compiler.v2i2.50 